Article

\title{
A Limited Rapid Assessment of Forest Regeneration in 24 Cypress and Tupelo Bottomland Swamps Following Clearcutting and Shovel Logging in the Coastal Plain of North Carolina
}

\author{
James N. Slye, Albert J. Lang *(-) and Tom A. Gerow Jr. \\ North Carolina Forest Service, Raleigh, NC 27699, USA; james.slye@ncagr.gov (J.N.S.); \\ tom.a.gerow@ncagr.gov (T.A.G.J.) \\ * Correspondence: aj.lang@ncagr.gov; Tel.: +1-919-857-4857
}

Received: 8 July 2020; Accepted: 1 August 2020; Published: 6 August 2020

check for updates

\begin{abstract}
A rapid regeneration survey within twenty-four deepwater swamps between stand ages 2 and 14 years in the North Carolina coastal plain was conducted by using a narrow rectangular inventory technique ("strip cruise"). Inventoried tracts predominantly contained cypress (Taxodium distichum) and tupelo (Nyssa species) before being harvested via clearcutting methods. Single transects on each tract began at coordinates located in the interior of the harvest areas in locations representing general tract conditions. Each transect was perpendicular to the flow of the major stream drainage associated with the harvest area. Counts and measures of dead and live stumps and seed-sourced regeneration were recorded. About 52 percent of desirable timber species stumps tallied had coppice growth. However, coppice alone was not sufficient on any tract to exceed 1112 trees ha ${ }^{-1}$. Seventy-one percent of tracts had stocking levels (coppice and seed source) at least 1112 trees ha $^{-1}$ of desirable timber species or black willow (Salix nigra). Across 24 tracts, 42 percent regenerated cypress and/or tupelo to levels exceeding 1112, trees ha ${ }^{-1}$. This assessment revealed that forest regeneration success was limited on sites with altered hydrology, rampant invasive species, and/or lack of seed source. In some cases, active forest management may improve the regeneration cohort. Overall, shovel logging methods that were used on evaluated sites appear to be compatible with adequate regeneration of desirable timber species if the proper conditions exist. Additionally, we assessed species' composition within a harvested stand measured at age eight years (a previous study) and age 68 years (measured for this study), for a comparison perspective. Results revealed a species composition change from willow at age eight years to a mixed stand of desirable timber species at age 68 years. This finding supports other studies that have recorded the successional pattern of pioneering willow shifting to desirable timber species as willow stagnates and diminishes in abundance due to natural mortality.
\end{abstract}

Keywords: bottomland swamp; cypress-tupelo; regeneration; timber harvest; strip cruise; coppice

\section{Introduction}

Bald cypress (Taxodium distichum) and tupelo species (Nyssa spp.) are important components of North Carolina's one million ha of bottomland forests [1]. These species commonly coexist on permanently flooded or poorly drained sites with low levels of sediment deposition, often referred to as muck swamps, backwater swamps, or deepwater swamps [2-4]. Bald cypress and tupelo species are uniquely adapted to withstand prolonged inundation and, if minimally disturbed, can remain dominant in the overstory for hundreds of years $[4,5]$. However, disturbances that create stand-level gaps such as timber harvesting, wind storms, fire, or stream channel disturbances that alter hydrology can affect site conditions to an extent that will influence the subsequent vegetation successional 
patterns [6]. Cypress and tupelo species are not known to readily propagate advanced regeneration in the understory and often regenerate better in large canopy openings [7]. Because cypress and tupelo species require a relatively dry period during the growing season to become established by seed, regeneration in deepwater swamps can take many years. Ideal establishment conditions may not occur for years following a major disturbance and are largely controlled by factors external to stand boundaries.

Regenerating swamp forests so that native tree species diversity is maintained is a common forest management objective and is an important step in protecting ecosystem functions and values [8-10]. Large-scale harvesting of forests, including swamps, occurred across the Southeastern United States until the middle of the 20th century [4]. Many of these cutover deepwater swamps naturally regrew desirable timber species following various complex successional patterns, much of which was not intensively monitored or studied [5]. After several decades of ensuing growth, these bottomland areas are now reaching economic maturity with regard to timber. This financial investment driver, coupled with modern harvesting methods (e.g., shovel or mat logging), and diverse markets for forest products, has led to a resurgence of timber harvesting in bottomland areas of North Carolina and abroad. A clearcut regeneration method is frequently implemented in these swamp forests because of economical and silvicultural drivers. Costs associated with specialized harvesting systems (i.e., shovel logging) tend to exceed the costs of upland pine operations due to the difficulty and extra precaution needed to minimize impacts on wet-natured soils. Therefore, repeated stand entry associated with uneven management strategies is less attractive to landowners who have a financial interest as their primary objective, but also want to minimize environmental impacts. Subsequently, a renewed interest in sustainability and how deepwater swamp sites regenerate cypress-tupelo has drawn focus on these forest systems.

Because deepwater sites tend to have longer timber rotations and are more challenging to operationally access than upland timber types, fewer research studies have been designed, replicated, examined for long-term effects, and reported in peer-reviewed articles [11-13]. To help fill this knowledge gap, the objective of this assessment was to provide a broad assessment of cypress-tupelo regeneration or stocking levels within 24 deepwater swamps at various stand ages in North Carolina. Additionally, a comparison of data between stand ages 8 and 68 years is discussed for one unique tract. The results should benefit forest owners and managers by providing findings that can be considered when identifying goals and management strategies for similar forest types of the South Atlantic Coastal Plain in the United States.

\section{Materials and Methods}

\subsection{Site Selection}

Approximately 100 privately owned tracts were identified by the North Carolina Forest Service (NCFS) based upon personal knowledge, forest industry and conservation group contacts, or satellite imagery observations. Sites eligible for this assessment met the following conditions: (1) The tract was clearcut harvested within the previous 15 years of the assessment, by use of the shovel logging method, and allowed to naturally regenerate; (2) the preharvest tree canopy was dominated by cypress-tupelo; (3) the tract is located within the North Carolina Coastal Plain; and (4) the tract will remain in silvicultural land-use. The NCFS requested permission to access each site and conduct regeneration surveys. Where permission was granted, investigators selected the first 24 tracts that met the above criteria and which were distributed across as many river basins as feasible within the state's Coastal Plain (Figure 1). 


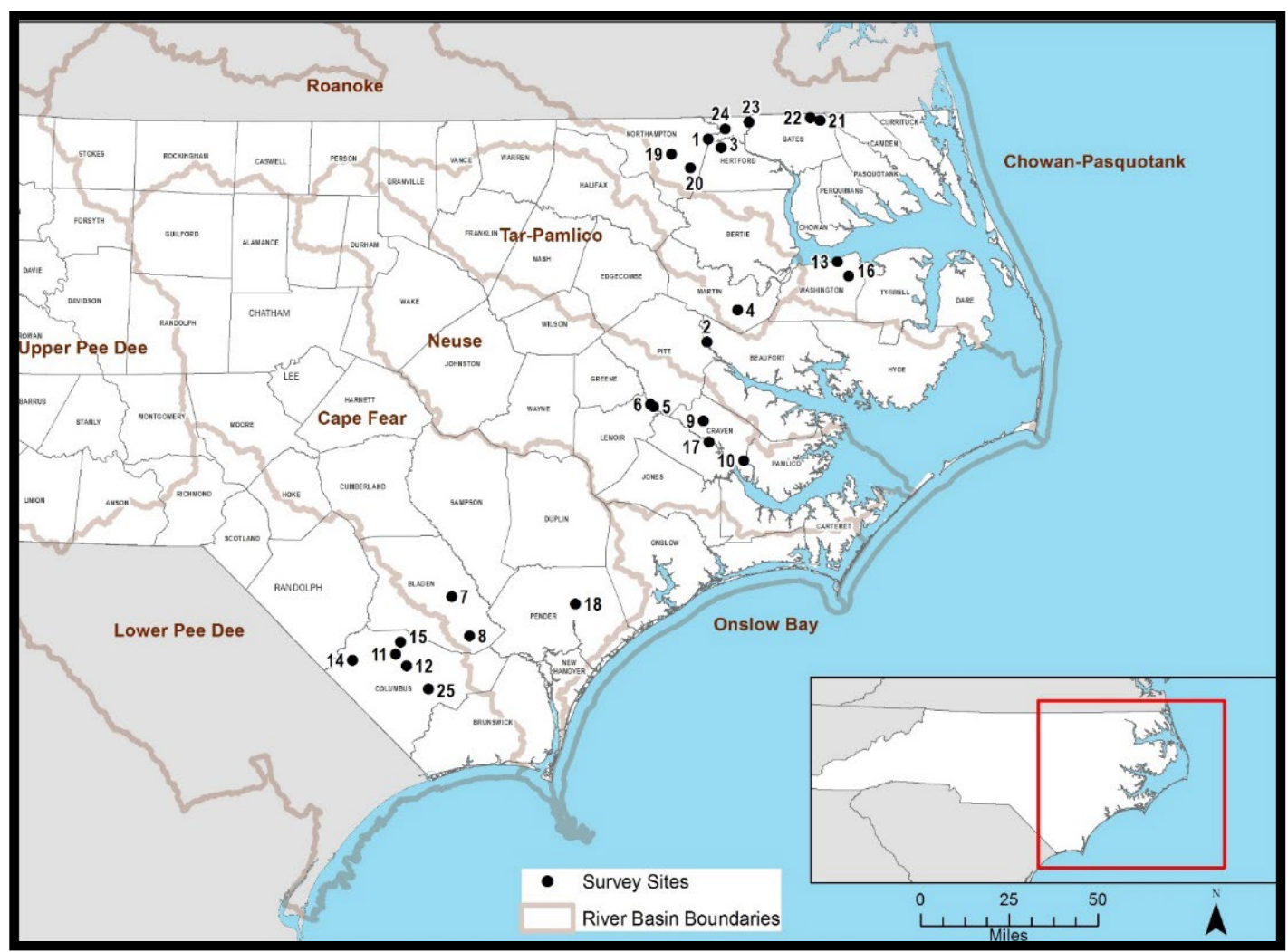

Figure 1. Approximate survey site locations displayed with counties and major river basins of Eastern North Carolina.

\subsection{Site Description}

A list of surveyed site information is found in Table 1. Twenty-four sampled tracts had stand ages between 2 and 14 years. These tracts were all clearcut harvested, using the shovel logging method, and ranged from 2 to 383 ha in deepwater swamp clearcut area. No seed trees, other than in streamside management zones (where applicable), were observed on sampled tracts. Regeneration of these sites depends largely on seeds floating in from offsite, animal distribution, coppice, the seed bank remaining from the previously harvested timber, and/or management action to artificially plant desired trees. The decision to clearcut was made by each landowner. It was the investigators' opinion that shovel logging was the only feasible harvesting method, aside from some form of aerial or cable yarding, which are infrequently used to harvest timber in the Atlantic Coastal Plain. The shovel logging method of timber harvesting involves a track-mounted felling machine, a track-mounted, tree-handling/log-loader machine, and a skidding machine. Trees are felled and placed atop the ground, in a finger-jointed pattern, to create a skid trail. Felled timber is shuttled along this trail to the log deck, for merchandizing and staging. Once the trail is no longer needed, the trees and logs that were used to build the trail are pulled up and merchandized [14]. 
Table 1. Locations, year of timber harvest, stand age at the time of survey, and soil characteristics of each tract evaluated for regeneration.

\begin{tabular}{|c|c|c|c|c|c|c|c|}
\hline Tract & County & Major River Basin/Minor Basin & Year Harvested & Age & Size (ha) & Soil Series & Soil Texture \\
\hline 1 & Hertford & Chowan/Meherrin/Kirby's Creek & 2013 & 3 & 12 & Dorovan soils & Organic muck \\
\hline 2 & Beaufort & Tar-Pamlico/Tranter's Creek & 2014 & 2 & 40 & Ponzer muck, rarely flooded & Organic muck \\
\hline 3 & Hertford & Chowan/Meherrin & 2011 & 5 & 12 & Dorovan soils & Organic muck \\
\hline 4 & Martin & Roanoke/Yarrell Creek & 2014 & 2 & 2 & Bibb loam, frequently flooded & Loamy sand/Sandy loam \\
\hline 5 & Pitt & Neuse/Contentnea Creek & 2011 & 5 & 13 & Bibb loam, frequently flooded & Loamy sand/Sandy loam \\
\hline 6 & Pitt & Neuse/Contentnea Creek & 2007 & 9 & 8 & Bibb complex, frequently flooded & $\begin{array}{l}\text { Sandy loam/Loamy } \\
\text { sand/Mucky loam }\end{array}$ \\
\hline 7 & Bladen & Cape Fear/Black & 2013 & 3 & 383 & $\begin{array}{l}\text { Croatan muck, } 0-2 \% \text {, } \\
\text { frequently ponded }\end{array}$ & Organic muck \\
\hline 8 & Bladen & Cape Fear & 2011 & 5 & 24 & $\begin{array}{l}\text { Chewacla/Chastain soils, } \\
\text { frequently flooded }\end{array}$ & Silt loam/Silty clay \\
\hline 9 & Craven & Neuse/Swift Creek & 2010 & 6 & 12 & $\begin{array}{l}\text { Masontown/Muckalee fine sandy loam, } \\
\text { frequently flooded }\end{array}$ & $\begin{array}{l}\text { Mucky fine sandy } \\
\text { loam/Sandy loam }\end{array}$ \\
\hline 10 & Craven & Neuse/Broad Creek & 2011 & 5 & 22 & $\begin{array}{l}\text { Masontown/Muckalee fine sandy loam, } \\
\text { frequently flooded }\end{array}$ & $\begin{array}{l}\text { Mucky fine sandy } \\
\text { loam/Sandy loam }\end{array}$ \\
\hline 11 & Columbus & Pee Dee/Lumber/Waccamaw & 2009 & 7 & 170 & Johnston loam, frequently flooded & Mucky loam \\
\hline 12 & Columbus & Pee Dee/Lumber/Waccamaw & 2009 & 7 & 189 & Johnston loam, frequently flooded & Mucky loam \\
\hline 13 & Washington & Chowan/Deep Creek & 2005 & 11 & 42 & Dorovan muck, frequently flooded & Organic muck \\
\hline 14 & Columbus & $\begin{array}{c}\text { Pee Dee/Lumber/Cerro Gordo } \\
\text { Swamp }\end{array}$ & 2003 & 13 & 6 & Johnston loam, frequently flooded & Mucky loam \\
\hline 15 & Columbus & Pee Dee/Lumber/Waccamaw & 2004 & 12 & 72 & Johnston loam, frequently flooded & Mucky loam \\
\hline 16 & Washington & Chowan/Deep Creek & 2014 & 2 & 41 & Dorovan muck, frequently flooded & Organic muck \\
\hline 17 & Craven & Neuse & 2010 & 6 & 5 & Dorovan muck, frequently flooded & Organic muck \\
\hline 18 & Pender & Cape Fear/Northeast Cape Fear & 2011 & 5 & 45 & Muckalee loam, frequently flooded & Loam \\
\hline 19 & Northampton & Chowan/Meherrin & 2011 & 5 & 51 & Wehadkee loam, frequently flooded & Loam \\
\hline 20 & Northampton & Chowan/Meherrin & 2003 & 13 & 36 & Chastain silt loam, frequently flooded & Silt loam/Silty clay \\
\hline 21 & Gates & Pasquotank/Great Dismal Swamp & 2003 & 14 & 29 & Chowan loam, frequently flooded & Silt loam/Silty clay loam \\
\hline 22 & Gates & Pasquotank/Great Dismal Swamp & 2007 & 10 & 46 & Chowan loam, frequently flooded & Silt loam/Silty clay loam \\
\hline 23 & Hertford & Chowan & 1949 & 68 & 32 & Dorovan soils & Organic muck \\
\hline 24 & Hertford & Chowan/Meherrin & 2005 & 12 & 59 & Dorovan soil/Wehadkee silt loam & Organic muck/Loam \\
\hline 25 & Columbus & Pee Dee/Lumber/Waccamaw & 2010 & 6 & 61 & $\begin{array}{l}\text { Dorovan muck/Johnston loam, } \\
\text { frequently flooded }\end{array}$ & Organic muck/Mucky loam \\
\hline
\end{tabular}


Contrarily, Tract 23 was surveyed at the stand age of 68 years and employed a different timber harvest method. In 1949, timber was hand-felled and yarded, using a high lead cable extraction system, set along the upland edge of the tract $[15,16]$. This tract was not included within our data analysis when comparing regeneration metrics of the other 24 tracts. Instead, it was only compared to earlier stand regeneration data collected at the stand age 8 years, by a graduate student at Duke University [15]. This same project (at stand age 8 years) was later published in a U.S. Department of Agriculture Forest Service research note [16].

Tract 7 had received a supplemental planting of cypress on $4.6 \mathrm{~m}$ by $4.6 \mathrm{~m}$ spacing prior to the assessment. The planted cypress seedlings on Tract 7 were readily distinguishable from natural regeneration; thus, this distinction was recorded in the data.

Selected sites were located within 11 counties of the middle and outer Coastal Plain of North Carolina. These sites were located within 11 major river basins and 18 sub-river basins, which included both black-water and red-water river systems [5]. Presumptively, none of the sites received any mechanical or chemical site preparation prior to or after timber harvest operations. Each site was categorized into one of three Society of American Foresters (SAF) cover types: SAF 102 (Bald Cypress-tupelo), SAF 103 (Water Tupelo (Nyssa aquatica)/Swamp Tupelo (Nyssa biflora)), or SAF 104 (Sweet Bay (Magnolia virginiana)/Swamp Tupelo/Red Bay (Persea borbonia)) [17]. Eleven soil series consisting of poorly drained to very poorly drained soils were encountered across sample sites and identified by using the USDA's Natural Resources Conservation Service Web Soil Survey ${ }^{\mathrm{TM}}$. Soil orders included entisols, inceptisols, and histosols, all of which are typical of such sites. Soil series included the following: Bibb series (coarse-loamy, siliceous, active, acid, thermic Typic Fluvaquents), Chastain series (fine, mixed, semi-active, acid, thermic Fluvaquentic Endoaquepts), Chewacla series (fine-loamy, mixed, active, thermic Fluvaquentic Dystrudepts), Chowan series (fine-silty, mixed, active, nonacid, thermic Thapto-Histic Fluvaquents), Croatan series (loamy, siliceous, dysic, thermic Terric Haplosaprists), Dorovan series (dysic, thermic Typic Haplosaprists), Johnston series (coarse-loamy, siliceous, active, acid, thermic Cumulic Humaquepts), Masontown series (coarse-loamy, siliceous, active, nonacid, thermic Cumulic Humaquepts), Muckalee series (coarse-loamy, siliceous, superactive, nonacid, thermic Typic Fluvaquents), Ponzer series (loamy, mixed, dysic, thermic Terric Haplosaprists), and Wehadkee series (fine-loamy, mixed, active, nonacid, thermic Fluvaquentic Endoaquepts) [18].

\subsection{Field Sample Location, Measurements, and Data Classifications}

Tracts were inventoried between the summer of 2016 and summer of 2017. Prior to field site visits, points and azimuths for the beginning transect were identified by using the most recent GoogleEarth ${ }^{\mathrm{TM}}$ imagery. Investigators selected starting points, from a 1:24,000 or greater map scale, that represented the overall appearance and were well within the interior of the tract boundaries. Latitude and longitude were recorded and input into a Garmin ${ }^{\circledR}$ GPS 62, for later field navigation. A narrow rectangular inventory sample ("strip cruise"), consisting of a total transect length of $100.1 \mathrm{~m}$ and $5.0 \mathrm{~m}$ wide (0.05 ha), was implemented on each of the 24 tracts used in the analysis. Transects intersected locations where shovel trails were previously located, but they were not distinguished in the dataset. Furthermore, streamside management zones were not sampled. Tract 23 (tract not used in the data analysis) required a larger sampling strategy to more accurately capture stocking levels. At this tract, a strip cruise consisting of three transects $10.1 \mathrm{~m}$ wide and $100.1 \mathrm{~m}$ long ( $0.30 \mathrm{ha})$ was implemented. All inventory transects were oriented perpendicular to the flow of the major stream system associated with the harvest area, to sample variations in vegetation influenced by micro-topographical and associated water table differences. In order to acquire the total transect length objective, multiple uneven transect lengths were necessary on some sites, as the total distance along the single parallel line was less than $100.1 \mathrm{~m}$.

Transect azimuth was established by using a hand compass. Transect distances were measured by using a fiberglass surveyor's tape. This surveyor's tape also served as the centerline for transect width measurements. The transect width was measured by utilizing a $2.4 \mathrm{~m}$ survey range pole. Tree species 
were identified, and height $(\mathrm{m})$ and/or diameter at breast height $(\mathrm{cm})$ were measured and subsequently categorized into the following ranges: sawtimber $(\geq 35.6 \mathrm{~cm} \mathrm{DBH})$, pole timber $(\geq 12.7 \mathrm{~cm}$ to $<35.6 \mathrm{~cm}$ $\mathrm{DBH})$, sapling $(\geq 1.4 \mathrm{~m}$ tall and $<12.7 \mathrm{~cm} \mathrm{DBH})$, and seedling $(<1.4 \mathrm{~m}$ tall). Investigators also classified regeneration as coppice regeneration (regeneration originating from sprouting on harvested stumps) or seed regeneration.

Dead stumps were identified (where distinguishable) and tallied according to species, or otherwise tallied as "unknown" or "indeterminate". A dead stump tallied as unknown meant the tree species could not be reasonably identified. Dead and live stump heights were recorded in $0.3 \mathrm{~m}$ increments and measured by using a marked range pole. Both dead- and live-stump diameters were recorded in $2.54 \mathrm{~cm}$ increments. Dead stumps classified as indeterminate were those in which the aboveground portion of the stump had deteriorated to the extent that height, diameter, and tree species both could not be reasonably estimated or identified. We also added into the indeterminate category the dead stumps below water level, where a measurement could not be accurately made. Finally, on live stumps, the count of coppice sprouts per stump was recorded.

Stands were classified as either stocked or understocked, using a threshold level of 1112 trees ha $^{-1}$. Stands were categorized by predominate species into cypress-tupelo, willow (Salix nigra), or mixed species. Segregation into these categories was based on a two-thirds percentage of species composition. If cypress-tupelo or willow were less than two-thirds of a stand, it was classified as mixed. A list of desirable timber species found in stands classified as being mixed are found in Table 2.

Table 2. Timber species other than cypress-tupelo (Taxodium-Nyssa species) present on tracts classified as "mixed". Mixed tracts contained at least two-thirds composition of one or more of the listed species below. Other vegetation (e.g., shrubs, vines, and herbaceous plants) were present, but not recorded.

\begin{tabular}{cc}
\hline Common Name & Scientific Name \\
\hline American elm & Ulmus americana \\
Eastern cottonwood & Populus deltoides \\
Green ash & Fraxinus pennsylvanica \\
Laurel oak & Quercus laurifolia \\
Loblolly pine & Pinus taeda \\
Overcup oak & Quercus lyrata \\
Red maple & Acer rubrum \\
Swamp cottonwood & Populus heterophylla \\
Sweetgum & Liquidambar styraciflua \\
Sycamore & Platanus occidentalis \\
Water hickory & Carya aquatica \\
\hline
\end{tabular}

\subsection{Data Analysis}

Descriptive statistics of stump and seed source characteristics were calculated. Measured variables were compared to stand age, using Spearman's rank correlation coefficient analyses. All analyses were conducted with JMP ${ }^{\circledR}$ Pro 14.2.0 Statistical Discovery Software [19].

\section{Results}

\subsection{Overall Regeneration}

Across the 24 tracts, 71 percent exceeded a threshold stocking level of 1112 trees $^{-1}$, with the sum of cypress, tupelo, willow, and other desirable timber species stocking (Tables 3 and 4). This finding suggests that clearcutting with the shovel logging method can be compatible with adequate regeneration of desirable timber species within deepwater swamp forests when proper site conditions exist postharvest. 
Table 3. Stand age, trees per hectare (TPH), and percent of TPH categorized as coppice and seed source by cypress (Taxodium distichum), tupelo (Nyssa species), and black willow (Salix nigra) for each of the 25 tracts evaluated.

\begin{tabular}{|c|c|c|c|c|c|c|c|c|c|c|c|c|c|c|c|c|}
\hline \multirow{3}{*}{ Tract } & \multirow{3}{*}{ Age } & \multicolumn{5}{|c|}{ Cypress } & \multicolumn{5}{|c|}{ Tupelo } & \multicolumn{5}{|c|}{ Willow } \\
\hline & & \multirow{2}{*}{ TPH } & \multirow{2}{*}{ Coppice (\%) } & \multicolumn{3}{|c|}{ Seed Source (\%) } & \multirow{2}{*}{ TPH } & \multirow{2}{*}{ Coppice (\%) } & \multicolumn{3}{|c|}{ Seed Source $(\%)$} & \multirow{2}{*}{ TPH } & \multirow{2}{*}{ Coppice (\%) } & \multicolumn{3}{|c|}{ Seed Source (\%) } \\
\hline & & & & Seedlings & Saplings & Poles & & & Seedlin & aplings & Poles & & & Seedlings & Saplings & Poles \\
\hline 1 & 3 & 316 & 44 & 56 & 0 & 0 & 217 & 55 & 9 & 36 & 0 & 20 & 0 & 100 & 0 & 0 \\
\hline $3 *+$ & 5 & 3855 & 2 & 50 & 48 & 0 & 633 & 50 & 13 & 37 & 0 & 2214 & 0 & 12 & 88 & 0 \\
\hline $4 *+$ & 2 & 20 & 0 & 100 & 0 & 0 & 2214 & 9 & 91 & 0 & 0 & 0 & 0 & 0 & 0 & 0 \\
\hline 5 & 5 & 20 & 0 & 100 & 0 & 0 & 79 & 100 & 0 & 0 & 0 & 158 & 0 & 63 & 37 & 0 \\
\hline 6 & 9 & 376 & 5 & 0 & 84 & 11 & 0 & 0 & 0 & 0 & 0 & 0 & 0 & 0 & 0 & 0 \\
\hline $7 *+$ & 3 & 395 & 0 & 90 & 10 & 0 & 1344 & 1 & 99 & 0 & 0 & 20 & 0 & 100 & 0 & 0 \\
\hline $8 *+$ & 5 & 1087 & 11 & 29 & 60 & 0 & 1067 & 37 & 20 & 43 & 0 & 59 & 0 & 0 & 100 & 0 \\
\hline 9 & 6 & 0 & 0 & 0 & 0 & 0 & 0 & 0 & 0 & 0 & 0 & 158 & 12 & 25 & 63 & 0 \\
\hline 10 * & 5 & 474 & 0 & 42 & 58 & 0 & 59 & 67 & 0 & 33 & 0 & 2254 & 4 & 1 & 95 & 0 \\
\hline $11^{*}+$ & 7 & 158 & 2 & 0 & 98 & 0 & 7769 & 2 & 0 & 98 & 0 & 1937 & 0 & 0 & 93 & 7 \\
\hline $12 *$ & 7 & 99 & 0 & 20 & 80 & 0 & 119 & 17 & 0 & 83 & 0 & 1838 & 0 & 0 & 98 & 2 \\
\hline $13^{*}+$ & 11 & 59 & 0 & 0 & 100 & 0 & 1364 & 16 & 12 & 72 & 0 & 119 & 0 & 0 & 100 & 0 \\
\hline $14^{*}$ & 13 & 277 & 0 & 21 & 57 & 21 & 376 & 0 & 0 & 95 & 5 & 554 & 4 & 0 & 46 & 50 \\
\hline $15 *+$ & 12 & 277 & 0 & 0 & 71 & 29 & 3558 & 12 & 0 & 79 & 9 & 870 & 0 & 0 & 27 & 73 \\
\hline 16 & 2 & 20 & 0 & 100 & 0 & 0 & 217 & 91 & 9 & 0 & 0 & 178 & 0 & 33 & 67 & 0 \\
\hline $17^{*}+$ & 6 & 830 & 2 & 10 & 88 & 0 & 969 & 12 & 0 & 88 & 0 & 1542 & 0 & 0 & 100 & 0 \\
\hline 20 * & 13 & 20 & 0 & 0 & 100 & 0 & 59 & 0 & 0 & 100 & 0 & 1977 & 0 & 0 & 81 & 19 \\
\hline 21 & 14 & 0 & 0 & 0 & 0 & 0 & 178 & 0 & 0 & 33 & 67 & 573 & 0 & 0 & 14 & 86 \\
\hline $22 *+$ & 10 & 59 & 0 & 0 & 100 & 0 & 2847 & 10 & 88 & 2 & 0 & 79 & 0 & 0 & 25 & 75 \\
\hline $23 * \diamond$ & 68 & 234 & 7 & 0 & 15 & 63 & 656 & 11 & $<1$ & 33 & 51 & 7 & 0 & 0 & 0 & 100 \\
\hline $24 *+$ & 12 & 4942 & 1 & 0 & 99 & 0 & 5990 & 3 & 0 & 97 & 0 & 40 & 0 & 0 & 100 & 0 \\
\hline $25^{*}$ & 6 & 356 & 6 & 6 & 88 & 0 & 79 & 50 & 0 & 50 & 0 & 79 & 0 & 25 & 75 & 0 \\
\hline
\end{tabular}
"stocked" threshold of 1112 trees pe sawtimber-sized trees, for the Seed Source subcategory. This tract was excluded from data analysis due to a differing harvest technique and stand age (unless stated otherwise). 
Table 4. Stand age, trees per hectare (TPH), and percent of TPH categorized as coppice and seed source for desirable timber species for each of the 25 tracts evaluated. This includes species listed in Table 2, Cypress (Taxodium distichum), and Tupelo (Nyssa species).

\begin{tabular}{|c|c|c|c|c|c|c|c|}
\hline \multicolumn{8}{|c|}{ Desirable Timber Species } \\
\hline \multirow{2}{*}{ Tract } & \multirow{2}{*}{ Age } & \multirow{2}{*}{ ТPH } & \multirow{2}{*}{ Coppice (\%) } & \multicolumn{4}{|c|}{ Seed Source $(\%)$} \\
\hline & & & & Seedlings & Saplings & Poles & Sawtimber \\
\hline 1 & 3 & 554 & 46 & 40 & 14 & 0 & 0 \\
\hline $2 *$ & 2 & 138 & 100 & 0 & 0 & 0 & 0 \\
\hline $3 *+$ & 5 & 4843 & 10 & 42 & 48 & 0 & 0 \\
\hline $4 *+$ & 2 & 2254 & 10 & 90 & 0 & 0 & 0 \\
\hline 5 & 5 & 99 & 80 & 20 & 0 & 0 & 0 \\
\hline 6 & 9 & 455 & 4 & 0 & 87 & 9 & 0 \\
\hline $7 *+$ & 3 & 1898 & 5 & 92 & 3 & 0 & 0 \\
\hline $8 *+$ & 5 & 2155 & 24 & 25 & 51 & 0 & 0 \\
\hline 9 & 6 & 0 & 0 & 0 & 0 & 0 & 0 \\
\hline 10 * & 5 & 1107 & 27 & 23 & 50 & 0 & 0 \\
\hline $11 *+$ & 7 & 9924 & 5 & 1 & 93 & 1 & 0 \\
\hline 12 * & 7 & 593 & 20 & 3 & 77 & 0 & 0 \\
\hline $13 *+$ & 11 & 3064 & 26 & 9 & 65 & 0 & 0 \\
\hline $14^{*}$ & 13 & 6820 & 2 & 9 & 87 & 2 & 0 \\
\hline $15^{*}+$ & 12 & 4824 & 9 & 1 & 80 & 1 & 0 \\
\hline 16 & 2 & 316 & 63 & 37 & 0 & 0 & 0 \\
\hline $17^{*}+$ & 6 & 2016 & 9 & 4 & 87 & 0 & 0 \\
\hline $18^{*}$ & 5 & 395 & 10 & 37 & 53 & 0 & 0 \\
\hline 19 & 5 & 415 & 24 & 24 & 47 & 5 & 0 \\
\hline $20 *$ & 13 & 1206 & 13 & 2 & 80 & 5 & 0 \\
\hline 21 & 14 & 217 & 9 & 0 & 36 & 55 & 0 \\
\hline $22 *+$ & 10 & 3064 & 12 & 0 & 84 & 4 & 0 \\
\hline $23 * \diamond$ & 68 & 1549 & 7 & 0 & 48 & 40 & 5 \\
\hline $24 *+$ & 12 & 10,952 & 2 & 0 & 98 & 0 & 0 \\
\hline $25 *$ & 6 & 1265 & 19 & 3 & 78 & 0 & 0 \\
\hline
\end{tabular}

* Tracts that exceeded "stocked" threshold of 1112 trees per hectare (includes Taxodium distichum, Nyssa species, Salix nigra, and desirable timber species listed in Table 2). + Tracts that exceeded "stocked" threshold of 1112 trees per hectare with only Taxodium distichum and Nyssa species. ${ }^{\diamond}$ This tract's plot also contained $15 \%$ Taxodium distichum and 5\% Nyssa species sawtimber-sized trees, for the Seed Source subcategory. This tract was excluded from data analysis due to a differing harvest technique and stand age (unless stated otherwise).

\subsubsection{Cypress, Tupelo, and Other Desirable Timber Species}

Cypress stocking ranged from 0 to 4942 trees $\mathrm{ha}^{-1}$, and the median was 218 trees ha ${ }^{-1}$ (Table 3). Tupelo stocking ranged from 0 to 7769 trees ha $^{-1}$, with a median of 217 trees ha $^{-1}$ (Table 3). Cypress and tupelo species alone exceeded the threshold stocking level in 42 percent of surveyed tracts. All desirable timber species (including cypress and tupelo) ranged from 0 to 10,952 trees $^{-1}$, and the median was 1236 trees ha ${ }^{-1}$ (Table 4 ).

Of the 42 percent of cypress and tupelo stocked tracts, less than 10 percent of the stems originated from coppicing stumps (when only one sprout was counted per stump). The relatively low stand stocking levels and sporadic spacing of coppiced cypress and tupelo stumps found in our assessment align well with several other published studies [20-24]. However, it is possible that some single coppice stems could have been misclassified as originating from seed source, if portions of the parent/source tree were hidden below the waterline, muck, or sediment. Coppicing may provide greater levels of regeneration on some sites, yet it does not appear to be as reliable as seed-sourced regeneration on our examined sites.

The potential influence of cypress and tupelo coppicing to support future stand development after clearcutting should not be discounted [25]. Coppicing stumps that remain viable for several years following disturbances may provide a supplemental seed source to regenerate the harvested area back 
to adequate stocking levels. Some bottomland swamp stands require multiple years after disturbance to reach desired stocking levels, due to natural variable cycles of hydrology, seed production, and herbivory [26].

Twelve percent of counted cypress stumps had coppice. Forty-three percent of counted tupelo had coppice. Note that dead unknown stump species were added to the denominator of cypress and tupelo percent coppice calculation. Therefore, these percent coppice calculations represent the lowest possible percentage based on the collected data. A Spearman's rank correlation coefficient analysis revealed a significant negative relationship between the dead stumps ha ${ }^{-1}$ and stand age $(\varrho=-0.53$, $p<0.01$ ). This suggests that, as the stand ages, fewer stumps will be observed (likely due to stump deterioration). Investigators noted several instances of substantial stump decay in coppicing stumps for stand ages less than 10 years. This corresponds well with the findings of Keim et al. [24] where coppice sprouts that survived past age 10 were less likely to succumb to decay and more likely to remain in the overstory than sprouts less than age 10 years.

Across the 24 tracts, a median of 0 coppicing cypress stumps ha ${ }^{-1}$, with a range of 0 to 138 coppicing stumps ha ${ }^{-1}$, was recorded (Table 5). A median of 89 coppicing tupelo stumps ha ${ }^{-1}$, with a range of 0 to 415 coppicing stumps ha ${ }^{-1}$, was recorded (Table 6). A median of 188 coppicing desirable species stumps ha ${ }^{-1}$, with a range of 0 to 791 coppicing stumps ha ${ }^{-1}$, was also recorded (Table 7). The average number of sprouts per coppiced stump was 7 and 32 for cypress and tupelo, respectively. On tracts that exceed 1112 trees ha ${ }^{-1}$ of cypress and tupelo, the average stump survival was 19 and 64 percent for cypress and tupelo, respectively. No significant trends between coppice stump heights, diameters, or count of sprouts were identified within this dataset $(p>0.1)$. No studies reporting the influence of cypress or tupelo stump height effect on long-term coppice survival were identified; however, several short-term studies exist [23,25,27]. Randell et al. [25] found that coppice of pond cypress (Taxodium distichum var. nutans) stumps in Florida that were cut level with, or $20 \mathrm{~cm}$ below, the high-water mark had more viable sprouts after two years than from stumps that were cut at least $20 \mathrm{~cm}$ above the high-water mark. Survival rate of coppice sprouts in their study ranged from 23 to 54 percent across eight sites. Within our dataset, 54 percent of desirable species stumps sprouted across the 24 sites. Cypress and tupelo stumps without coppicing (i.e., dead stumps identified as either cypress or tupelo) averaged 114 stumps ha ${ }^{-1}$, and the median was 30 stumps ha $^{-1}$. These data ranged from 0 to 474 stumps ha ${ }^{-1}$. When dead stumps of unknown species were added to the dataset of dead cypress and tupelo stumps, an average of 203 dead stumps ha ${ }^{-1}$ and a median of 138 dead stumps $\mathrm{ha}^{-1}$ were recorded. No significant trends between dead stump heights or diameters were identified by using Spearman's rank correlation coefficient analyses $(p>0.10)$. 
Table 5. Count, height, and diameter of live cypress (Taxodium distichum) stumps and stump survival by each of the 25 tracts evaluated.

\begin{tabular}{|c|c|c|c|c|c|c|c|c|c|c|c|c|c|c|c|c|}
\hline \multirow[b]{2}{*}{ Tract } & \multirow[b]{2}{*}{ Age } & \multirow{2}{*}{$\begin{array}{l}\text { Count of } \\
\text { Stumps }\end{array}$} & \multirow[b]{2}{*}{$\begin{array}{l}\text { Count of } \\
\text { Sprouts }\end{array}$} & \multirow{2}{*}{$\underset{(\%)}{\text { Stump Survival } \ddagger}$} & \multirow{2}{*}{$\begin{array}{l}\text { Stumps Per } \\
\text { Hectare }\end{array}$} & \multicolumn{6}{|c|}{ Frequency Range of Stump Height $(\mathrm{m})$} & \multicolumn{5}{|c|}{ Frequency Range of Stump Diameter $(\mathrm{cm})$} \\
\hline & & & & & & $\begin{array}{c}\text { Less than } \\
0.45\end{array}$ & $\begin{array}{l}0.46 \text { to } \\
0.76\end{array}$ & $\begin{array}{c}0.76 \text { to } \\
1.06\end{array}$ & $\begin{array}{c}1.07 \text { to } \\
1.37\end{array}$ & $\begin{array}{c}1.37 \text { to } \\
1.67\end{array}$ & Indet. & $\begin{array}{l}\text { Less } \\
\text { than } 45\end{array}$ & $\begin{array}{c}46 \text { to } \\
76\end{array}$ & $\begin{array}{c}76 \text { to } \\
106\end{array}$ & $\begin{array}{c}107 \text { to } \\
137\end{array}$ & Indet. \\
\hline 1 & 3 & 7 & 72 & 70 & 138 & 3 & 3 & 0 & 0 & 1 & 0 & 1 & 5 & 1 & 0 & 0 \\
\hline $2 *$ & 2 & 2 & 25 & 9 & 40 & 0 & 2 & 0 & 0 & 0 & 0 & 0 & 2 & 0 & 0 & 0 \\
\hline $3 *+$ & 5 & 3 & 21 & 50 & 59 & 0 & 3 & 0 & 0 & 0 & 0 & 0 & 3 & 0 & 0 & 0 \\
\hline $4 *+$ & 2 & 0 & 0 & 0 & 0 & 0 & 0 & 0 & 0 & 0 & 0 & 0 & 0 & 0 & 0 & 0 \\
\hline 5 & 5 & 0 & 0 & 0 & 0 & 0 & 0 & 0 & 0 & 0 & 0 & 0 & 0 & 0 & 0 & 0 \\
\hline 6 & 9 & 1 & 1 & 13 & 20 & 1 & 0 & 0 & 0 & 0 & 0 & 0 & 1 & 0 & 0 & 0 \\
\hline $7^{*+}+$ & 3 & 0 & 0 & 0 & 0 & 0 & 0 & 0 & 0 & 0 & 0 & 0 & 0 & 0 & 0 & 0 \\
\hline $8 *+$ & 5 & 6 & 18 & 75 & 119 & 0 & 0 & 0 & 0 & 0 & 6 & 0 & 0 & 0 & 0 & 6 \\
\hline 9 & 6 & 0 & 0 & 0 & 0 & 0 & 0 & 0 & 0 & 0 & 0 & 0 & 0 & 0 & 0 & 0 \\
\hline $10 *$ & 5 & 0 & 0 & 0 & 0 & 0 & 0 & 0 & 0 & 0 & 0 & 0 & 0 & 0 & 0 & 0 \\
\hline $11 *+$ & 7 & 0 & 0 & 0 & 0 & 0 & 0 & 0 & 0 & 0 & 0 & 0 & 0 & 0 & 0 & 0 \\
\hline $12 *$ & 7 & 0 & 0 & 0 & 0 & 0 & 0 & 0 & 0 & 0 & 0 & 0 & 0 & 0 & 0 & 0 \\
\hline $13 *+$ & 11 & 0 & 0 & 0 & 0 & 0 & 0 & 0 & 0 & 0 & 0 & 0 & 0 & 0 & 0 & 0 \\
\hline $14^{*}$ & 13 & 0 & 0 & 0 & 0 & 0 & 0 & 0 & 0 & 0 & 0 & 0 & 0 & 0 & 0 & 0 \\
\hline $15^{*}+$ & 12 & 0 & 0 & 0 & 0 & 0 & 0 & 0 & 0 & 0 & 0 & 0 & 0 & 0 & 0 & 0 \\
\hline 16 & 2 & 0 & 0 & 0 & 0 & 0 & 0 & 0 & 0 & 0 & 0 & 0 & 0 & 0 & 0 & 0 \\
\hline $17^{*}+$ & 6 & 1 & 2 & 10 & 20 & 0 & 1 & 0 & 0 & 0 & 0 & 0 & 1 & 0 & 0 & 0 \\
\hline $18 *$ & 5 & 3 & 11 & 16 & 59 & 2 & 1 & 0 & 0 & 0 & 0 & 0 & 3 & 0 & 0 & 0 \\
\hline 19 & 5 & 2 & 3 & 8 & 40 & 2 & 0 & 0 & 0 & 0 & 0 & 1 & 1 & 0 & 0 & 0 \\
\hline $20 *$ & 13 & 0 & 0 & 0 & 0 & 0 & 0 & 0 & 0 & 0 & 0 & 0 & 0 & 0 & 0 & 0 \\
\hline 21 & 14 & 0 & 0 & 0 & 0 & 0 & 0 & 0 & 0 & 0 & 0 & 0 & 0 & 0 & 0 & 0 \\
\hline $22 *+$ & 10 & 0 & 0 & 0 & 0 & 0 & 0 & 0 & 0 & 0 & 0 & 0 & 0 & 0 & 0 & 0 \\
\hline $23 * \diamond$ & 68 & 5 & 12 & 42 & 16 & 1 & 1 & 0 & 1 & 1 & 1 & 0 & 3 & 0 & 1 & 1 \\
\hline $24 *+$ & 12 & 3 & 13 & 50 & 59 & 1 & 0 & 1 & 1 & 0 & 0 & 0 & 2 & 1 & 0 & 0 \\
\hline $25^{*}$ & 6 & 1 & 1 & 13 & 20 & 1 & 0 & 0 & 0 & 0 & 0 & 0 & 1 & 0 & 0 & 0 \\
\hline
\end{tabular}

* Tracts that exceeded "stocked" threshold of 1112 trees per hectare (includes the sum of Taxodium distichum, Nyssa species, Salix nigra, and desirable timber species listed in Table 2. + Tracts that exceeded "stocked" threshold of 1112 trees per hectare with only Taxodium distichum and Nyssa species. $\diamond$ This tract was excluded from data analysis due to a differing harvest technique and stand age (unless stated otherwise). $\ddagger$ Percent of recorded Taxodium distichum stumps that coppiced. Calculated by dividing the count of live Taxodium distichum coppicing stumps by the sum of dead and alive stump counts identified as Taxodium distichum or unknown. Indet. = indeterminate. 
Table 6. Count, height, and diameter of live tupelo (Nyssa species) stumps and percent of surviving stumps by each of the 25 tracts evaluated.

\begin{tabular}{|c|c|c|c|c|c|c|c|c|c|c|c|c|c|c|c|c|c|c|}
\hline \multirow[b]{2}{*}{ Tract } & \multirow[b]{2}{*}{ Age } & \multirow{2}{*}{$\begin{array}{l}\text { Count of } \\
\text { Stumps }\end{array}$} & \multirow{2}{*}{$\begin{array}{l}\text { Count of } \\
\text { Sprouts }\end{array}$} & \multirow{2}{*}{$\underset{(\%)}{\text { Stump }_{(\%)}^{\text {Survival }}}{ }^{\Delta}$} & \multirow{2}{*}{$\begin{array}{c}\text { Sprouts Per } \\
\text { Hectare }\end{array}$} & \multicolumn{8}{|c|}{ Frequency Range of Stump Height (m) } & \multicolumn{5}{|c|}{ Frequency Range of Stump Diameter $(\mathrm{cm})$} \\
\hline & & & & & & $\begin{array}{c}\text { Less than } \\
0.45\end{array}$ & $\begin{array}{c}0.46 \text { to } \\
0.76\end{array}$ & $\begin{array}{c}0.76 \text { to } \\
1.06\end{array}$ & $\begin{array}{c}1.07 \text { to } \\
1.37\end{array}$ & $\begin{array}{c}1.37 \text { to } \\
1.67\end{array}$ & $\begin{array}{c}1.68 \text { to } \\
1.98\end{array}$ & $\begin{array}{c}2.29 \text { to } \\
2.59\end{array}$ & Indet. & $\begin{array}{c}\text { Less } \\
\text { than } 45\end{array}$ & $\begin{array}{c}46 \text { to } \\
76\end{array}$ & $\begin{array}{c}76 \text { to } \\
106\end{array}$ & $\begin{array}{c}107 \text { to } \\
137\end{array}$ & Indet. \\
\hline 1 & 3 & 6 & 34 & 27 & 119 & 2 & 2 & 0 & 1 & 0 & 0 & 1 & 0 & 1 & 4 & 1 & 0 & 0 \\
\hline $2 *$ & 2 & 5 & 25 & 16 & 99 & 0 & 2 & 1 & 2 & 0 & 0 & 0 & 0 & 4 & 1 & 0 & 0 & 0 \\
\hline $3 *+$ & 5 & 16 & 79 & 84 & 316 & 9 & 5 & 2 & 0 & 0 & 0 & 0 & 0 & 2 & 9 & 4 & 1 & 0 \\
\hline $4 *+$ & 2 & 10 & 72 & 31 & 198 & 2 & 5 & 2 & 0 & 1 & 0 & 0 & 0 & 1 & 5 & 3 & 1 & 0 \\
\hline 5 & 5 & 4 & 33 & 44 & 79 & 0 & 0 & 0 & 0 & 0 & 0 & 4 & 0 & 2 & 1 & 0 & 1 & 0 \\
\hline 6 & 9 & 0 & 0 & 0 & 0 & 0 & 0 & 0 & 0 & 0 & 0 & 0 & 0 & 0 & 0 & 0 & 0 & 0 \\
\hline $7^{*}+$ & 3 & 1 & 4 & 10 & 20 & 1 & 0 & 0 & 0 & 0 & 0 & 0 & 0 & 0 & 1 & 0 & 0 & 0 \\
\hline $8 *+$ & 5 & 20 & 54 & 95 & 395 & 0 & 0 & 0 & 0 & 0 & 0 & 0 & 20 & 0 & 0 & 0 & 0 & 20 \\
\hline 9 & 6 & 0 & 0 & 0 & 0 & 0 & 0 & 0 & 0 & 0 & 0 & 0 & 0 & 0 & 0 & 0 & 0 & 0 \\
\hline $10^{*}$ & 5 & 2 & 9 & 29 & 40 & 1 & 0 & 1 & 0 & 0 & 0 & 0 & 0 & 1 & 0 & 1 & 0 & 0 \\
\hline $11{ }^{*}+$ & 7 & 8 & 26 & 100 & 158 & 6 & 1 & 1 & 0 & 0 & 0 & 0 & 0 & 2 & 2 & 2 & 0 & 2 \\
\hline $12 *$ & 7 & 1 & 6 & 33 & 20 & 0 & 0 & 0 & 0 & 0 & 1 & 0 & 0 & 0 & 0 & 0 & 1 & 0 \\
\hline $13 *+$ & 11 & 11 & 63 & 26 & 217 & 4 & 0 & 1 & 0 & 0 & 0 & 0 & 6 & 0 & 0 & 1 & 0 & 10 \\
\hline $14^{*}$ & 13 & 0 & 0 & 0 & 0 & 0 & 0 & 0 & 0 & 0 & 0 & 0 & 0 & 0 & 0 & 0 & 0 & 0 \\
\hline $15 *+$ & 12 & 21 & 146 & 81 & 415 & 0 & 21 & 0 & 0 & 0 & 0 & 0 & 0 & 21 & 0 & 0 & 0 & 0 \\
\hline 16 & 2 & 10 & 96 & 26 & 198 & 4 & 2 & 4 & 0 & 0 & 0 & 0 & 0 & 0 & 10 & 0 & 0 & 0 \\
\hline $17^{*}+$ & 6 & 6 & 17 & 50 & 119 & 1 & 0 & 0 & 0 & 0 & 0 & 0 & 5 & 0 & 1 & 0 & 0 & 5 \\
\hline $18^{*}$ & 5 & 0 & 0 & 0 & 0 & 0 & 0 & 0 & 0 & 0 & 0 & 0 & 0 & 0 & 0 & 0 & 0 & 0 \\
\hline 19 & 5 & 3 & 9 & 20 & 59 & 2 & 1 & 0 & 0 & 0 & 0 & 0 & 0 & 0 & 2 & 0 & 0 & 1 \\
\hline $20 *$ & 13 & 0 & 0 & 0 & 0 & 0 & 0 & 0 & 0 & 0 & 0 & 0 & 0 & 0 & 0 & 0 & 0 & 0 \\
\hline 21 & 14 & 0 & 0 & 0 & 0 & 0 & 0 & 0 & 0 & 0 & 0 & 0 & 0 & 0 & 0 & 0 & 0 & 0 \\
\hline $22 *+$ & 10 & 15 & 50 & 88 & 297 & 9 & 5 & 0 & 1 & 0 & 0 & 0 & 0 & 1 & 4 & 9 & 1 & 0 \\
\hline $23 * \Delta$ & 68 & 22 & 55 & 76 & 72 & 6 & 8 & 0 & 0 & 0 & 0 & 0 & 8 & 0 & 7 & 6 & 1 & 8 \\
\hline $24 *+$ & 12 & 10 & 47 & 71 & 198 & 4 & 1 & 3 & 1 & 1 & 0 & 0 & 0 & 1 & 3 & 4 & 2 & 0 \\
\hline $25 *$ & 6 & 2 & 3 & 22 & 40 & 0 & 1 & 1 & 0 & 0 & 0 & 0 & 0 & 1 & 0 & 1 & 0 & 0 \\
\hline
\end{tabular}

* Tracts that exceeded "stocked" threshold of 1112 trees per hectare (includes all desirable timber species (Table 2) and Salix nigra). + Tracts that exceeded "stocked" threshold of 1112 trees per hectare for cypress and tupelo (Taxodium distichum and Nyssa species). ${ }^{\diamond}$ This tract was excluded from the data analysis due to a differing harvest technique and stand age. ${ }^{\Delta}$ Percent of recorded Nyssa species stumps that coppiced. Calculated by dividing the count of live Nyssa species coppicing stumps by the sum of dead and alive stump counts identified as Nyssa species and unknown. 
Table 7. Count of stumps and stump sprouts, percent of surviving stumps, and height and diameter of live cypress (Taxodium distichum), tupelo (Nyssa species), and all other desirable species listed in Table 2 by each of the 25 tracts evaluated.

\begin{tabular}{|c|c|c|c|c|c|c|c|c|c|c|c|c|c|c|c|c|c|c|}
\hline \multirow[b]{2}{*}{ Tract } & \multirow[b]{2}{*}{ Age } & \multirow{2}{*}{$\begin{array}{l}\text { Count of } \\
\text { Stumps }\end{array}$} & \multirow{2}{*}{$\begin{array}{l}\text { Count of } \\
\text { Sprouts }\end{array}$} & \multirow{2}{*}{$\underset{(\%)}{\text { Stump Survival }}$} & \multirow{2}{*}{$\begin{array}{l}\text { Sprouts Per } \\
\text { Hectare }\end{array}$} & \multicolumn{8}{|c|}{ Frequency Range of Stump Height (m) } & \multicolumn{5}{|c|}{ Frequency Range of Stump Diameter (cm) } \\
\hline & & & & & & $\begin{array}{c}\text { Less than } \\
0.45\end{array}$ & $\begin{array}{c}0.46 \text { to } \\
0.76\end{array}$ & $\begin{array}{l}0.76 \text { to } \\
1.06\end{array}$ & $\begin{array}{c}1.07 \text { to } \\
1.37\end{array}$ & $\begin{array}{c}1.37 \text { to } \\
1.67\end{array}$ & $\begin{array}{c}1.68 \text { to } \\
1.98\end{array}$ & $\begin{array}{c}2.29 \text { to } \\
2.59\end{array}$ & Indet. & $\begin{array}{l}\text { Less } \\
\text { than } 45\end{array}$ & $\begin{array}{c}46 \text { to } \\
76\end{array}$ & $\begin{array}{c}76 \text { to } \\
106\end{array}$ & $\begin{array}{c}107 \text { to } \\
137\end{array}$ & Indet. \\
\hline 1 & 3 & 13 & 106 & 45 & 257 & 5 & 5 & 0 & 0 & 2 & 0 & 1 & 0 & 2 & 9 & 2 & 0 & 0 \\
\hline $2 *$ & 2 & 7 & 50 & 16 & 138 & 0 & 4 & 1 & 2 & 0 & 0 & 0 & 0 & 4 & 3 & 0 & 0 & 0 \\
\hline $3 *+$ & 5 & 25 & 123 & 89 & 494 & 15 & 8 & 2 & 0 & 0 & 0 & 0 & 0 & 8 & 12 & 4 & 1 & 0 \\
\hline $4 *+$ & 2 & 11 & 78 & 31 & 217 & 2 & 5 & 2 & 0 & 1 & 0 & 0 & 1 & 1 & 5 & 3 & 1 & 1 \\
\hline 5 & 5 & 4 & 33 & 27 & 79 & 0 & 0 & 0 & 0 & 0 & 0 & 4 & 0 & 2 & 1 & 0 & 1 & 0 \\
\hline 6 & 9 & 1 & 1 & 14 & 20 & 1 & 0 & 0 & 0 & 0 & 0 & 0 & 0 & 0 & 1 & 0 & 0 & 0 \\
\hline $7 *+$ & 3 & 5 & 23 & 33 & 99 & 5 & 0 & 0 & 0 & 0 & 0 & 0 & 0 & 4 & 1 & 0 & 0 & 0 \\
\hline $8 *+$ & 5 & 26 & 72 & 93 & 514 & 0 & 0 & 0 & 0 & 0 & 0 & 0 & 26 & 0 & 0 & 0 & 0 & 26 \\
\hline 9 & 6 & 0 & 0 & 0 & 0 & 0 & 0 & 0 & 0 & 0 & 0 & 0 & 0 & 0 & 0 & 0 & 0 & 0 \\
\hline $10^{*}$ & 5 & 20 & 125 & 80 & 395 & 17 & 2 & 1 & 0 & 0 & 0 & 0 & 0 & 12 & 7 & 1 & 0 & 0 \\
\hline $11^{*}+$ & 7 & 26 & 147 & 100 & 514 & 23 & 1 & 1 & 1 & 0 & 0 & 0 & 0 & 11 & 7 & 4 & 0 & 4 \\
\hline $12 *$ & 7 & 6 & 33 & 75 & 119 & 4 & 1 & 0 & 0 & 0 & 1 & 0 & 0 & 2 & 1 & 0 & 1 & 2 \\
\hline $13 *+$ & 11 & 40 & 190 & 91 & 791 & 21 & 1 & 1 & 1 & 0 & 0 & 0 & 16 & 12 & 1 & 2 & 0 & 25 \\
\hline $14^{*}$ & 13 & 8 & 24 & 36 & 158 & 8 & 0 & 0 & 0 & 0 & 0 & 0 & 0 & 8 & 0 & 0 & 0 & 0 \\
\hline $15 *+$ & 12 & 23 & 159 & 77 & 455 & 0 & 23 & 0 & 0 & 0 & 0 & 0 & 0 & 23 & 0 & 0 & 0 & 0 \\
\hline 16 & 2 & 10 & 96 & 26 & 198 & 4 & 2 & 4 & 0 & 0 & 0 & 0 & 0 & 0 & 10 & 0 & 0 & 0 \\
\hline $17^{*}+$ & 6 & 9 & 23 & 45 & 178 & 2 & 1 & 0 & 0 & 0 & 0 & 0 & 6 & 1 & 1 & 1 & 0 & 6 \\
\hline $18^{*}$ & 5 & 4 & 20 & 18 & 40 & 3 & 1 & 0 & 0 & 0 & 0 & 0 & 0 & 0 & 4 & 0 & 0 & 0 \\
\hline 19 & 5 & 5 & 12 & 17 & 99 & 4 & 1 & 0 & 0 & 0 & 0 & 0 & 0 & 1 & 3 & 0 & 0 & 0 \\
\hline $20 *$ & 13 & 8 & 61 & 50 & 158 & 4 & 2 & 0 & 0 & 0 & 0 & 0 & 2 & 2 & 3 & 1 & 0 & 2 \\
\hline 21 & 14 & 1 & 8 & 20 & 20 & 1 & 0 & 0 & 0 & 0 & 0 & 0 & 0 & 0 & 1 & 0 & 0 & 0 \\
\hline $22 *+$ & 10 & 18 & 65 & 90 & 356 & 12 & 5 & 0 & 1 & 0 & 0 & 0 & 0 & 3 & 5 & 9 & 1 & 0 \\
\hline $23 * \diamond$ & 68 & 31 & 76 & 82 & 102 & 9 & 10 & 0 & 1 & 1 & 0 & 0 & 10 & 1 & 11 & 7 & 2 & 10 \\
\hline $24 *+$ & 12 & 13 & 60 & 65 & 257 & 5 & 1 & 4 & 2 & 1 & 0 & 0 & 0 & 1 & 5 & 5 & 2 & 0 \\
\hline $25 *$ & 6 & 12 & 106 & 60 & 237 & 4 & 5 & 3 & 0 & 0 & 0 & 0 & 0 & 3 & 2 & 6 & 1 & 0 \\
\hline
\end{tabular}

* Tracts that exceeded "stocked" threshold of 1112 trees per hectare (includes all desirable timber species and willow). † Tracts that exceeded "stocked" threshold of 1112 trees per hectare for cypress-tupelo (Taxodium-Nyssa species). $\diamond$ This tract was excluded from the data analysis due to a differing harvest technique and stand age. $\square$ Percent coppicing stumps is the count of coppicing cypress and tupelo stumps divided by the sum of coppicing cypress and tupelo count, dead cypress and tupelo count, and dead unknown count. 


\subsubsection{Willow (Salix nigra)}

Willow stocking levels ranged from 0 to 2254 trees ha ${ }^{-1}$, averaged 718 trees $\mathrm{ha}^{-1}$, and the median was 168 trees ha ${ }^{-1}$ across the 24 tracts (Table 3). Willow alone exceeded the threshold stocking level in 29 percent of surveyed tracts. The rapid colonization of cutover swamps by willow appears to be a natural early successional phenomenon [5] and has been reported in other studies $[16,28]$. The seeds of willow germinate quickly upon reaching a seedbed with ideal conditions and do not require stratification like cypress-tupelo species do [29]. Dulohery et al. [30] found that, during the first two years of their study, a willow canopy provided some growth benefits to cypress by ameliorating herbaceous competition, hydrology, and soil temperature. Therefore, high levels of willows after a clearcut timber harvest may not necessarily be a result of modern alterations to the landscape, hydrology, or changing climatic conditions. It is understood that the willow is a short-lived pioneer species that tends to become decadent by a stand age of 35 years [31].

\subsubsection{Understocked Stands}

Stands with inadequate regeneration appear to be the result of unfavorable conditions for regeneration. Across the 24 tracts assessed, 29 percent were classified as understocked. Of these tracts, four were categorized as mixed species, two as willow, and one as cypress-and-tupelo-dominated stands. Desirable timber species stocking levels of these tracts ranged from 0 to 455 trees ha ${ }^{-1}$, and the median was 316 trees ha ${ }^{-1}$. Willow stocking levels of these tracts ranged from 0 to 573 trees ha ${ }^{-1}$, and the median was 158 trees ha ${ }^{-1}$. Although these stocking levels are below the desirable threshold for timber management, they still exceed planting recommendations for bottomland forest restoration [32]. Understocked stand ages ranged from 2 to 13 years. These stocking levels and ages were not correlated when using Spearman's rank correlation coefficient analyses $(p>0.1)$. This suggests that the time-since-disturbance alone cannot be used to accurately predict stocking levels. A common observation at each of the inadequately stocked tracts was the negative influence that elevated water levels had on regeneration success. Alterations to the natural hydrologic function affect regeneration viability of deep swamp tree species. On 33 percent of tracts, investigators noted impounded hydrologic conditions that almost certainly limited seedling regeneration. An assessment of the probable cause of the altered hydroperiods included state roadway and railroad embankments, beaver dams, or sloughs with water levels greater than $0.5 \mathrm{~m}$ depth. All understocked tracts had at least one of these negative hydrologic impacts. It appears unlikely that these sites will regenerate without relieving the impounded water, prolonged drought, or other management strategies to facilitate favorable conditions for the establishment of desired species. Regeneration on Tract 9 was also negatively impacted by an abundance of invasive alligator weed (Alternanthera philoxeroides). While invasive species were identified at all sites, the transect for Tract 9 was more than 95 percent covered by alligator weed, and similar observations were seen across the rest of this tract outside of the transect.

\subsection{Comparison of Tract 23 at Stand Ages 8 and 68}

In addition to the 24 shovel logged tracts, we had the opportunity to examine the long-term effects of clearcut harvesting on one additional tract, which was subject to a previous research study $[15,16]$. This 28.3 ha tract was delineated out of a larger stand of similar species' composition and harvested in 1949. Allen [16] states that the original stand showed no evidence of any previous harvest and contained 156 and 568 thousand board feet of cypress and tupelo, respectively (note, the scale was not provided by Allen, but Doyle is believed to be most probable). Allen [16] evaluated this site eight years postharvest and found it dominated by willow ranging from 4.6 to $7.6 \mathrm{~m}$ in height and cattails (species not reported). Cypress-tupelo was present on only eight of 47 plots sampled and was little affected by willow. Allen [16] noted that greater tupelo seedling establishment occurred near residual mature water tupelo trees remaining in the northeastern corner of the tract, compared to areas not adjacent to parent seed-source trees. 
The results of our assessment for this tract 68 years postharvest yielded a stocked, mixed stand (1549 trees ha $\left.{ }^{-1}\right)$. The stand contained 57 percent cypress and tupelo, and 0.5 percent willow. Approximately six percent of the stand was the result of coppice growth, indicating that some of the coppice observed early in the stand remained viable. This stand is best classified as pole-timber-sized, with approximately five percent of the stand being sawtimber-sized. Other species present included red maple (Acer rubrum), sweetgum (Liquidambar styraciflua), loblolly pine (Pinus taeda), sweetbay (Magnolia virginiana), green ash (Fraxinus pennsylvanica), pumpkin ash (Fraxinus profunda), and persimmon (Diospyros virginiana). The residual trees in the northeastern portion of the tract referenced by Allen [16] were identified during our assessment, and regeneration in the immediate vicinity was the most well-developed area of the previously harvested stand. His observations on the preharvest stand would seem to indicate that cypress and tupelo represent the climax forest type on this site. The current composition of this stand seems to support the germination "window of opportunity" described by Kroschel et al. [26].

\section{Discussion}

This assessment adds to the base of knowledge regarding the successional regeneration after timber is harvested from deep swamp forests of the South Atlantic Coastal Plain. Cypress and tupelo species and other shade intolerant to moderately tolerant tree species can be successfully regenerated at adequate stocking levels following clearcut timber harvests using shovel logging methods, if the proper conditions exist. Care must be taken to ensure that adequate sources for regeneration exist, and it is critical that the local site hydrology remains relatively free of major instream or beaver alterations, at least through the germination and establishment period. Seed distribution can occur postharvest, from adjacent stands, floodwaters, and animal distribution, but the extent to which this occurs likely varies by site. About one-third of the surveyed sites were negatively impacted by impounded hydrology or prolific invasive species.

Regeneration is best ensured by the presence of seed on site and the lack of standing water during the periods of germination and establishment. Wetland tree species' seeds require a moist, but non-inundated seedbed and sufficient time during the growing season to regenerate to heights that will not be overtopped by high water for prolonged periods. These factors are influenced by weather patterns and direct or indirect site modifications. Ideal conditions for germination and establishment may not occur immediately following timber harvests in instances where site hydrology is altered (i.e., excessive water is impounded on the site). Willow, an early successional species, was observed on almost all evaluated tracts. Forest managers should carefully evaluate the role of willow on-site (e.g., is it creating a better growing condition for desired species?) and tailor their management decisions accordingly.

The observations from this assessment point to the necessity of continued active management and monitoring after a harvest, to optimize reforestation objectives. Natural, unmanaged processes may regenerate the entire site to a desired future condition but should not be assumed as such. Forest owners and managers must remain vigilant, to manage the site in a way that mimics natural hydro-periods and provides suitable seed source to foster reforestation. Before undertaking a timber harvest, due-diligence is warranted, to examine the hydrological and forest conditions upstream and downstream of the management unit/stand, in order to recognize if limitations beyond the stand's boundaries may influence future regeneration and growth potential. Control of certain wildlife may be needed to reduce both hydrological impacts and damaging herbivory of new seedlings. In addition, control of invasive aquatic vegetation may be necessary on some sites.

Regeneration from seed was the primary mechanism for cypress and tupelo stocking levels in the swamp forests examined. Although cypress and tupelo coppicing was present in most stands, it appeared to be irregularly spatially distributed, and decay from stumps into the sprout was a noted concern by investigators. About 65 percent of all counted stumps had coppice, but coppice survival was lower in older stands. The relatively low levels of cypress and tupelo coppicing observed do 
not eliminate the potential influence it may still have for future stand development as unsuitable site conditions for germination and establishment may persist for several years. Once site conditions become ideal, coppice may provide a seed source.

Future research should address the following four questions: (1) What practices are most successful to regenerate a stand when a harvested site exhibits impounded hydrology? (2) What recommendations can be given for seed source proximity needed to adequately regenerate swamp forests? (3) What is the role of willow in fostering subsequent cohorts of desirable species and what are the effects of intermediate removal? (4) How long can stump sprouts remain a viable seed source when germination and establishment conditions are not suitable immediately after a harvest?

\section{Conclusions}

Research investigators evaluated early stand regeneration in deep swamp sites that had been clearcut with shovel logging methods in the Atlantic Coastal Plain of North Carolina. Most assessed sites were adequately stocked at levels suitable for timber management. Therefore, shovel-logging appears to be compatible with sustaining and managing these forests of intolerant to moderately tolerant trees. However, care must be taken to ensure that adequate seed distribution can occur postharvest and that hydrology at the site is not significantly altered from the previously developed stand. Each understocked site assessed in this study contained unsuitable establishment conditions due to elevated water and/or prolific invasive species. Investigators noted that the primary source or driver of the unfavorable regeneration conditions originated from beyond the harvest unit area, or, in some cases, the property ownership boundary.

Coppicing in deepwater swamps may more frequently be a supplementary role in regenerating clearcuts on deepwater swamps, by providing seed once the coppice-growth can yield seed. None of the sites in this assessment would have exceeded our defined stocking threshold of 1112 trees ha $^{-1}$ with coppice only. Much of the regeneration came from seed, likely fallen from the previously harvested timber or transported by water from upstream areas. While the scope of this study could benefit from additional study sites in similar stand age classes, the data trends seem to be of sufficient merit to generalize across the Atlantic Coastal Plain region.

Author Contributions: Conceptualization, J.N.S.; methodology, J.N.S.; field work and data collection, J.N.S., with assistance; formal analysis, A.J.L.; writing-original draft preparation, A.J.L.; writing-review and editing, J.N.S., A.J.L., and T.A.G.J.; project administration, J.N.S. All authors have read and agreed to the published version of the manuscript.

Funding: This project was funded by USDA Forest Service with a Landscape Scale Restoration Grant. Support was provided by the State and Private Forestry Program and North Carolina Forest Service.

Acknowledgments: Successful project implementation was made possible by the logistical support and local knowledge of the N.C. Forest Service's county and district personnel. We would also wish to acknowledge the generous access permitted by dozens of forestland owners across North Carolina. The authors thank the anonymous reviewers for their insightful comments to better this work.

Conflicts of Interest: The authors declare no conflict of interest.

\section{References}

1. Brown, M.J. Forests of North Carolina, 2016; Resource Update FS-152; USDA Forest Service, Southern Research Station: Asheville, NC, USA, 2018; p. 4. Available online: https://www.fs.usda.gov/treesearch/pubs/56828 (accessed on 6 December 2019).

2. Kellison, R.C.; Martin, J.P.; Hansen, G.D.; Lea, R. Regenerating and Managing Natural Stands of Bottomland Hardwoods; American Pulpwood Association: Washington, DC, USA, 1988; 26p.

3. Young, P.J.; Keeland, B.D.; Sharitz, R.R. Growth response of baldcypress (Taxodium distichum (L.) Rich.) to an altered hydrologic regime. Am. Mid. Nat. 1995, 133, 206-212. [CrossRef]

4. Conner, W.H.; Buford, M. Southern deepwater swamps. In Southern Forested Wetlands Ecology and Management; Messina, M.G., Conner, W.H., Eds.; Lewis Publishers/CRC Press: Boca Raton, FL, USA, 1998; pp. 261-287. 
5. Hodges, J.D. Development and ecology of bottomland hardwood sites. For. Ecol. Manag. 1997, 90, 117-125. [CrossRef]

6. Wharton, C.H.; Kitchens, W.M.; Pendelton, E.C.; Sipe, T.W. The Ecology of Bottomland Hardwood Swamps of the Southeast: A Community Profile; FWS/OBS-81/37; Biological Services Program, U.S. Fish and Wildlife Service: Washington, DC, USA, 1982; p. 133.

7. Wilhite, L.P.; Toliver, J.R. Taxodium distichum (L.) Rich. Baldcypress. In Silvics of North America: Volume 1. Conifers; Agriculture Handbook 654; Burns, R.M., Honkala, B.H., Eds.; USDA Forest Service: Washington, DC, USA, 1990; pp. 563-569.

8. Conner, W.H.; Toliver, J.R. Long-term trends in the bald cypress (Taxodium distichum) resource in Louisiana (USA). For. Ecol. Manag. 1990, 33-34, 543-557. [CrossRef]

9. Walbridge, M.R. Functions and values of forested wetlands in the southern United States. J. For. 1993, 91, 15-19.

10. Poorter, L. Are species adapted to their regeneration niche, adult niche, or both? Am. Nat. 2007, 169, 433-442. [CrossRef] [PubMed]

11. Rapp, J.; Shear, T.; Robison, D. Soil groundwater, and floristics of a southeastern United States blackwater swamp 8 years after clearcutting with helicopter and skidder extraction of the timber. For. Ecol. Manag. 2001, 149, 241-252. [CrossRef]

12. McKee, S.E.; Aust, W.M.; Seiler, J.R.; Strahm, B.D.; Schilling, E.B. Long-term site productivity of a tupelo-cypress swamp 24 years after harvesting disturbances. For. Ecol. Manag. 2012, 265, 172-180. [CrossRef]

13. Aust, W.M.; Bolding, M.C.; Barrett, S.M. Silviculture in forested wetlands: Summary of current forest operations, potential effects, and long-term experiments. Wetlands 2019, 1-16. [CrossRef]

14. North Carolina Forest Service, Forestry Leaflet \#BF-4: Harvesting timber using the shovel (Mat) Logging method. Available online: https://www.ncforestservice.gov/publications/Forestry\%20Leaflets/BF4.pdf (accessed on 20 August 2019).

15. Allen, P.H. A Tidewater Swamp Forest and Succession after Clearcutting. Master's Thesis, Duke University, Durham, NC, USA, 1958.

16. Allen, P.H. Black Willow Dominates Baldcypress-Tupelo Swamp Eight Years after Clear Cutting; Sta. Note SE-177; Southeastern Forest Experiment Station; USDA Forest Service: Asheville, NC, USA, 1962; p. 2.

17. Eyre, F.H. Forest Cover Types of the United States and Canada; Society of American Foresters: Washington, DC, USA, 1980; p. 1483.

18. Natural Resources Conservation Service. Official Soil Series Descriptions. Available online: https://www. nrcs.usda.gov/wps/portal/nrcs/detail/soils/survey/geo/?cid=nrcs142p2_053587 (accessed on 12 August 2019).

19. SAS Institute, Inc. Using JMP 14.2.0; SAS Institute Inc.: Cary, NC, USA, 2018.

20. Kennedy, H.E., Jr. Growth and survival of water tupelo coppice regeneration after six growing seasons. South. J. Appl. For. 1982, 6, 133-135. [CrossRef]

21. Conner, W.H.; Toliver, J.R.; Sklar, F.H. Natural regeneration of baldcypress [Taxodium distichum (L.) Rich.] in a Louisiana swamp. For. Ecol. Manag. 1986, 14, 305-317. [CrossRef]

22. Conner, W.H. Natural and Artificial Regeneration of Baldcypress [Taxodium distichum (L.) Rich.] in the Barataria Basins of Louisiana. Ph.D. Thesis, Louisiana State University, Baton Rouge, LA, USA, 1988.

23. Ewel, K.C. Sprouting by pondcypress (Taxodium distichum var. nutans) after logging. South. J. Appl. For. 1996, 20, 209-213. [CrossRef]

24. Keim, R.F.; Chambers, J.L.; Hughes, M.S.; Dimvo, L.D.; Conner, W.H.; Shaffer, G.P.; Gardiner, E.S.; Day, J.W., Jr. Long-term success of stump sprouts in high-graded baldcypress-water tupelo swamps in the Mississippi delta. For. Ecol. Manag. 2006, 234, 24-33. [CrossRef]

25. Randall, C.K.; DeLaune, M.L.; Vince, S.W.; English, R.J. Factors influencing stump sprouting by pondcypress (Taxodium distichum var. nutans (Ait.) Sweet). New For. 2005, 29, 245-260. [CrossRef]

26. Kroschel, W.A.; King, S.L.; Keim, R.F. Tree regeneration by seed in bottomland hardwood forests: A review. In Southeastern Naturalist, Proceedings of the 6th Thicket Science Conference: Watersheds and Waterflow, Nacogdoches, TX, USA, 17-19 April 2015; Cook, J., Ed.; Eagle Hill Institute: Steuben, ME, USA, 2016; Volume 15, pp. 42-60. [CrossRef]

27. DeBell, D.S. Establishment of Swamp Tupelo Seedlings after Regeneration Cuts; Sta. Note SE-164; Southeastern Forest Experiment Station; USDA Forest Service: Asheville, NC, USA, 1971; p. 7. 
28. Aust, W.M.; Schoenholtz, S.H.; Zaebst, T.W.; Szabo, B.A. Recovery status of a tupelo-cypress wetland seven years after disturbance: Silvicultural implications. For. Ecol. Manag. 1997, 90, 161-169. [CrossRef]

29. Pitcher, J.A.; Mcknight, J.S. Salix nigra (Marsh.) Black Willow. In Silvics of North America, Vol. 2 Hardwoods; Agric. Handbook, 654; Burns, R.M., Honkala, B.H., Eds.; USDA, Forest Service: Washington, DC, USA, 1990; pp. 768-772.

30. Dulohery, C.J.; Kolka, R.K.; McKelvin, M.R. Effects of a willow overstory on planted seedlings in a bottomland restoration. Ecol. Eng. 2000, 15, S57-S66. [CrossRef]

31. Johnson, R.L.; Shrophire, F.W. Bottomland hardwoods. In Silvicultural Systems for the Major Forest Types of the United States; Agriculture Handbook 445; Burns, R.M., Ed.; USDA Forest Service: Washington, DC, USA, 1983; pp. 175-179.

32. Allen, J.A.; Keeland, B.D.; Stanturf, J.A.; Clewell, A.F.; Kennedy, H.E., Jr. A guide to bottomland hardwood restoration. In U.S. Geologic Survey, Biological Resources Division Information and Technology Report; USGS/BRD/ITR-2000-0011; Gen Tech Rep. SRS-40; USDA Forest Service: Washington, DC, USA, 2001; 132p.

(C) 2020 by the authors. Licensee MDPI, Basel, Switzerland. This article is an open access article distributed under the terms and conditions of the Creative Commons Attribution (CC BY) license (http://creativecommons.org/licenses/by/4.0/). 